\title{
Examining the Use of Hofstede's Uncertainty Avoidance Construct in a Major Role in Ethics Research
}

\author{
Julia D. Davis ${ }^{1}$, Richard A. Bernardi ${ }^{1} \&$ Susan M. Bosco ${ }^{1}$ \\ ${ }^{1}$ Roger Williams University, United States \\ Correspondence: Richard A. Bernardi, Roger Williams University, United States. E-mail: rbernardi@rwu.edu
}

Received: June 29, 2012

Accepted: September 11, 2012

Online Published: December 7, 2012

doi:10.5539/ibr.v6n1p63

URL: http://dx.doi.org/10.5539/ibr.v6n1p63

\begin{abstract}
This research focused on research in the Journal of Business Ethics (hereafter JoBE), International Journal of Value Based Management (hereafter IJoVBM) and Teaching Business Ethics (hereafter TBE) that used Hofstede's uncertainty avoidance construct (hereafter UA). We identified research that used Hofstede's UA to significantly contribute to the development of hypotheses, to construct an independent variable or as an independent variable. Understanding how UA has been used could provide opportunities for future research that increases our understanding of differences in international behavior and/or perceptions. The data indicate that of the 77 articles, $66.2 \%$ used UA strictly to construct hypotheses, $5.2 \%$ to construct alternative cultural indices and $28.6 \%$ as an independent variable.
\end{abstract}

Keywords: Hofstede, ethics, uncertainty avoidance

\section{Introduction}

This research examines the use of Hofstede's cultural construct of UA in international ethics research; however, while we only report on Hofstede's UA construct, the majority of the research we examined in the course of this study included all of Hofstede's constructs.. UA is a surrogate for a society's relative willingness to tolerate ambiguous outcomes. Hofstede's $(1991,150)$ UA construct was calculated as the combined score for a series of three questions dealing with: rules orientation, employment stability, and nervousness or stress at work. Rules orientation examines the rigidity of an individual's beliefs about following rules. The employment stability factor reflects the anticipated tenure for the individual's current job. The stress-at-work factor reflects individuals' responses to statement about being nervous or tense at work.

The uses of Hofstede's cultural dimension of UA as noted above were reviewed as they occurred in the $J o B E$ as well as in the $I J O V B M$ and $T B E$; in 2004, the latter two journals were merged back into the JoBE. These categories allow readers to quickly search and understand what information is available in these journals. A similar data compilation was performed for the Journal of International Business by Rapp et al. (2011) who suggested that future researchers examine other journals to compliment their study. This is the second in a two part series of articles; the first article (Authors, 20xx) examined the use of Hofstede's UA construct as a definition or in a comparison role. In the process of our review, we define the use of UA in a major role as significantly contributing to the development of research hypotheses, to construct an independent variable or as an independent variable. Consequently, we grouped articles into these three categories. Taken together with our first article and Rapp et al., the data in these articles provide an insight into how UA has been used in international research - both in general (Rapp et al.) and specifically in the area of ethics (Authors).

\section{Methodology}

The first step in the data gathering process was to identify articles to examine from the $J o B E$, which has been published since 1982. We began by using the journal's online search function for 'UA'. To ensure that we identified all articles, we also used Google's Advanced Scholar searching for 'UA' in the JoBE. We included only original journal articles; book reviews, comments, discussions and rejoinders were not included in our analysis. While this journal has been published since 1982, the first use of Hofstede's UA construct was in 1990; so our study actually includes articles from 1990 through 2011 (e.g., a 22-year period). While this journal has been published since 1982, the first use of Hofstede's UA construct was in 1990; so our study actually includes articles from 1990 through 2011 (e.g., a 22-year period). 
While our primary aim was to include articles from the $J_{O B E}$, the publisher of this journal also published the IJoVBM from 1988 through 2003 and TBE from 1997 through 2003. These journals were 'merged into the JoBE' at the beginning of 2004. We submit that article counts in the $J o B E$ between 1988 and 2003 (i.e., when these journals were independently published) would be understated compared to other years if these journals were not considered in the article count. Consequently, our total article count and classifications include publications from the IJOVBM and TBE. After identifying the articles that included Hofstede's UA, the second step in the data gathering process was to determine how UA was used in each article. We classified the 77 articles as: significantly contributing to the development of research hypotheses, to construct an independent variable or as an independent variable. After classifying the articles, we subsequently reviewed the classifications for validation purposes and resolved any classification differences.

For the 22 years of this study, we initially identified 161 articles that used Hofstede's UA construct. Of the 77 articles that included Hofstede's UA, 70 were in the JoBE; five were in the IJOVBM; and, two were in TBE. The trend-line data in Figure 1 portray the growth in the use of Hofstede's UA in ethics research hypothesis development (dashed trend line) and as an independent variable (dotted trend line).

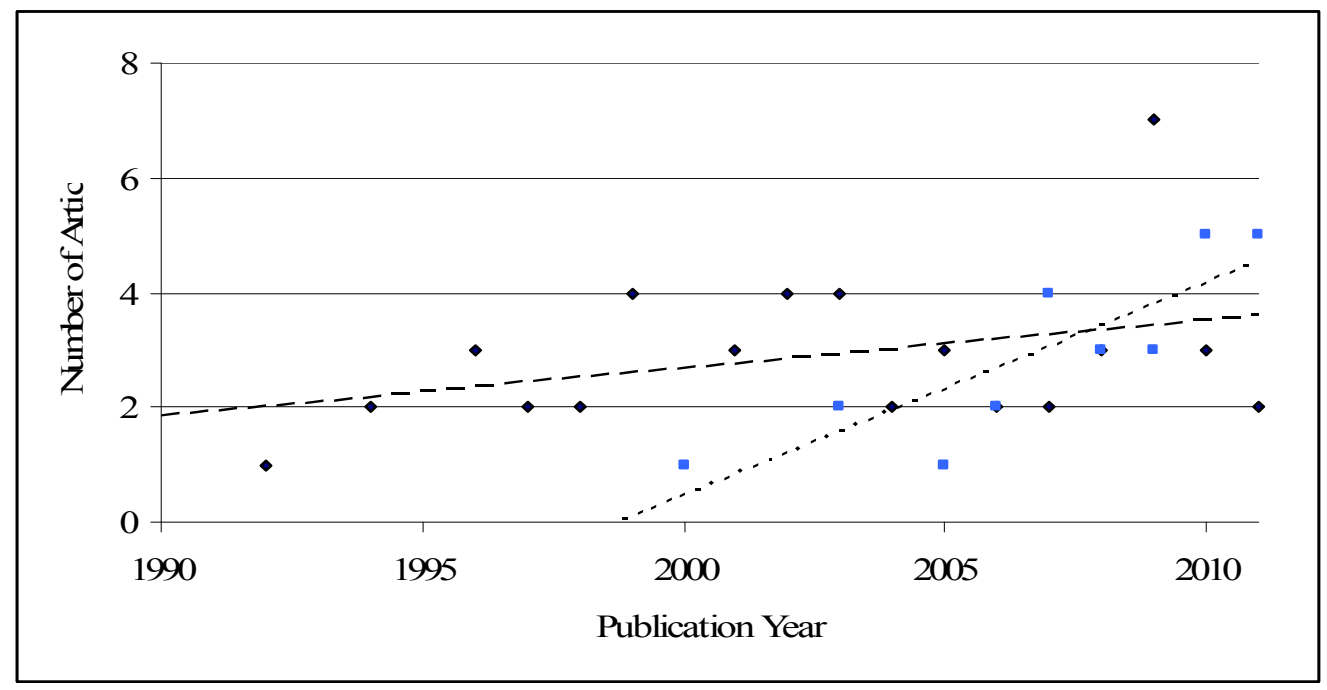

Figure 1. Number of articles using Hofstede's UA in ethics research by year

Note: Hypothesis development (diamonds and dashed trend line) and independent variable (squares and dotted trend line).

\section{Research Findings}

\subsection{Overview}

For the 22 years of this study, we found 77 articles. Figure 1 shows the increasing use of Hofstede's cultural dimension of UA in research shown in the JoBE, IJOVBM and TBE. Even though Hofstede's book first appeared in 1980 and cited four cultural dimensions including UA, the first article found in the $J o B E$ that referred to Hofstede's cultural dimension of UA did not appear until 1990. There are multiple reasons for the time lag between Hofstede's first article and the first article referring to his cultural dimensions in this journal. One reason is that research at that time was not as readily accessible as it is today. In addition, there is the concern that articles before 1990 were scanned into online databases which disallow users to search articles for keywords. Therefore there could potentially be articles before 1990 that referred to Hofstede's cultural dimensions, but they did not appear in these searches. The 77 articles that included UA were categorized into three groups. The first group of 51 articles uses UA in hypothesis development in the literature review. The second group includes four articles that use UA in addition to an alternative cultural index. The third group includes 22 articles that use UA as a variable in the research. The division into three groups allows readers to better organize the different uses of UA. The number of articles appearing in our tables exceeds the number of total articles in the study because four of the articles (Voyer and Beamish, 2004; Peng and Beamish, 2008; Salter et al., 2001; Li, 2008) appear in more than one table.

\subsection{Using UA in the Literature Review to Construct Hypotheses}

Table 1 includes articles that used UA in more depth in a literature review; Panel A includes articles that use UA for definitions, hypotheses or one-country studies; Panel B contains articles that use UA in ethics studies; Panel 
$\mathrm{C}$ articles use UA in two-country studies; and, Panel D includes articles that examine three or more countries. The 13 articles in Panel A of Table 1 include UA only in the literature reviews and can be subcategorized into three sections: definitions, hypotheses for research and one country studies. Seven simply describe UA (Robertson, 2002; Rallapalli, 1999; Vega 1997; Goodwin \& Goodwin, 1999; Thorne \& Saunder, 2002; Hoffman, 1998; Yang et al., 2009). Four use UA to support research hypotheses. These articles suggest an association between UA and Japan's success and negotiating effectiveness (Parnell \& Kedia, 1996), planning for the future (Lin \& Yeh, 2009), accounting firms and behaviors (Cohen et al., 1992), trust levels (Goel et al., 2005) and Confucian work dynamism (Woodbine, 2004). The last article in Panel A (Volkema \& Fleury, 2002) uses UA to describe the United States.

Panel B contains seven articles that use UA in ethics research. All suggested associations between UA and specific ethical behaviors or actions. Five found associations between UA and perceived ethical problems (Armstrong, 1996; Cherry et al., 2003), cheating (Salter et al., 2001), visible codes of ethics (Weaver, 2001), and validity of codes of ethics in Morocco (Oumlil \& Balloum, 2009). The other two articles in Panel B suggested associations between UA and ethics without specifically mentioning any particular aspect of ethics (De Bock \& Van Kenhove, 2010; Swaidan et al., 2006).

The articles in Panel C used UA in the literature review to contrast two countries. They compared Austria and Turkey (Smka et al., 2007), Japan and the Netherlands (Van Es \& Pels, 2010), Japanese and Hispanics (Fadil, 1997) and North Americans and Asians (Caldwell \& Clapham, 2003). Two articles include China in the two-country comparisons; Ge and Thomas (2008) compared China and Canada, while Tsui and Windsor (2001) compared China and Australia. Eight of the articles in Panel C compared the United States to: Brazil (Beekun et al., 2003), Croatia (Tavakoli et al., 2003), Egypt (Beekun et al., 2008), Jamaica (Sims \& Keenan, 1999), Korea (Kim et al., 2010), Mexico (Daspro, 2009), Spain (Vitell \& Hidalgo, 2006), Taiwan (Lu et al., 1999) and Turkey (Rawwas et al., 2005). The last article used UA to hypothesize about differences between the United States and Chinese based on manager incentives (Douglas \& Wier, 2005).

The articles in Panel D used UA in studies that compared three or more countries. Ten of the fourteen included the United States as one of the countries researched. These ten articles used UA to compare the United States to Australia, Israel, South Africa and Turkey (Sims \& Gegez, 2004), Canada, Colombia, Ecuador, Hong Kong and Ireland (Bernardi \& Guptill, 2008), Canada, France and UK (Freeman \& Hasnaoui, 2011), Canada, Hong Kong, Japan, Singapore and Thailand (Baker \& Veit, 1998), Canada and Mexico (Sower et al., 1998), China, France, Germany and Hong Kong (Ramasamy \& Yeung, 2009), Germany and Italy (Habisch et al., 2011), Hong Kong, Malaysia and Taiwan (Shafer et al., 2007), Thailand and Turkey (Burnaz et al., 2009) and Colombia, Ecuador and South Africa (Bernardi et al., 2009). The remaining four articles compared Australia, Canada and Sweden (Svensson et al., 2009), Gulf Cooperation Council Countries (At-Twaijri \& Al-Muhaiza, 1996), Mexico, China, France, Japan and Germany (Gulbro \& Herbig, 1998) and Latin American countries (Husted, 2002).

The Table 1 articles go into considerable detail concerning potential ethical differences as they relate to UA. All four panels include articles that used UA to support ethics research. There are nine articles that use one of Hofstede's stated connections between UA and behavioral contrasts (Table 1) in ethics research. They include: company rules should not be broken (Goodwin \& Goodwin, 1999; Throne \& Saunders, 2002; Cohen et al., 1992; Ge \& Thomas, 2008; Lu et al., 1999); higher resistance to change (Vega, 1997); and, higher corruption in wealthy countries (Volkema \& Fleury, 2002). Within Panel A, are five articles that highlight the associations between UA, behavioral contrasts and ethics. These articles describe that in high UA countries: company rules should be not broken (Goodwin \& Goodwin, 1999; Thorne \& Saunders, 2002; Cohen et al., 1992); there will be more resistance to change (Vega, 1997); and, corruption will be more prevalent in wealthy countries (Volkema \& Fleury, 2002). One article explains that high UA associates with greater fear of the future (Armstrong, 1996) and another states that in high UA societies only known risks are taken (Swaidan et al., 2006).

The collection of articles in Panel C includes Ge \& Thomas (2008) and Lu et al. (1999) which illustrate that, in high uncertainty avoidant societies, company rules should not be broken. In Panel D, one article (At-Twaijri \& Al-Muhaiza, 1996) explained that in high uncertainty avoidant countries, experts are given key positions. In Panel B, there was an association between high UA and an increased level of importance of ethical problems (Armstrong, 1996), decreased in perception of ethical problems (Cherry et al., 2003), increased visible ethics initiatives (Weaver, 2001), decreased self-regulations (Salter et al., 2001), increased cheating (Salter et al., 2001), increased cheating for internal reasons (Salter et al., 2001) and increased view that an absence of rules is a license to do as one desires (Swaidan et al., 2006). 
Table 1a. Literature Review Only Articles

\begin{tabular}{|c|c|c|}
\hline Author(s) & Year & Theoretical Premise \\
\hline \multicolumn{3}{|c|}{ Panel A: Definition, hypotheses for research and one-country studies } \\
\hline Robertson et al. & 2002 & Describes UA \\
\hline Rallapalli & 1999 & Describes UA \\
\hline Vega & 1997 & Describes UA \\
\hline Goodwin \& Goodwin & 1999 & Describes UA and Hofstede's methodology in ranking countries \\
\hline Parnell \& Kedia & 1996 & Describes UA and uses UA to explain Japan's success and negotiating effectiveness \\
\hline Thorne \& Saunders & 2002 & Describes UA and some applications \\
\hline Hoffman & 1998 & Describes UA and understanding cultural differences when expanding internationally \\
\hline Yang et al. & 2009 & Describes UA and said UA has little impact on software piracy \\
\hline Lin \& Yeh & 2009 & $\begin{array}{l}\text { Suggests UA positively associated with planning for future, working hard, and avoiding risky } \\
\text { activities and decisions }\end{array}$ \\
\hline Cohen et al. & 1992 & Suggests UA affects elements of accounting firms and behaviors \\
\hline Volkema \& Fleury & 2002 & Uses UA to describe US \\
\hline Goel et al. & 2005 & Suggests UA associated with levels of trust \\
\hline Woodbine & 2004 & Found no association between UA and Confucian work dynamism \\
\hline \multicolumn{3}{|c|}{ Panel B: Use in studies of ethics and codes of ethics } \\
\hline De Bock \& Van Kenhove & 2010 & Explained UA and suggested association with ethical beliefs \\
\hline Armstrong & 1996 & Suggests association between UA and perceived ethical problems \\
\hline Cherry et al. & 2003 & Suggests countries with high UA scores have fewer perceived ethical problems \\
\hline Weaver & 2001 & $\begin{array}{l}\text { Describes UA and suggest UA positively associated with focus on formal, visible codes of ethics } \\
\text { and practices }\end{array}$ \\
\hline Oumlil \& Balloun & 2009 & Uses UA to explain external validity of Moroccan companies' codes of ethics \\
\hline Salter et al. & 2001 & Associated likelihood of cheating to UA \\
\hline Swaidan et al. & 2006 & $\begin{array}{l}\text { Uses UA to hypothesize ethical differences and adherence ethical codes between developed and } \\
\text { less developed countries }\end{array}$ \\
\hline
\end{tabular}

Table 1b. Literature Review Only Articles

\begin{tabular}{|c|c|c|}
\hline Author(s) & Year & Theoretical Premise \\
\hline \multicolumn{3}{|c|}{ Panel C: Two country studies } \\
\hline Tsui \& Windsor & 2001 & Australia and China \\
\hline Srnka et al. & 2007 & Austria and Turkey \\
\hline Ge \& Thomas & 2008 & Canada and China \\
\hline Fadil & 1997 & Japanese and Hispanics \\
\hline Van Es \& Pels & 2010 & Japan and Netherlands \\
\hline Caldwell \& Clapham & 2003 & North Americans and Asians \\
\hline Beekun et al. & 2003 & US and Brazil \\
\hline Tavakoli et al. & 2003 & US and Croatia \\
\hline Beekun et al. & 2008 & US and Egypt \\
\hline Sims \& Keenan & 1999 & US and Jamaica \\
\hline Kim et al. & 2010 & US and Korea \\
\hline Daspro & 2009 & US and Mexico \\
\hline Vitell \& Hidalgo & 2006 & US and Spain \\
\hline Lu et al. & 1999 & US and Taiwan \\
\hline Rawwas et al. & 2005 & US and Turkey \\
\hline Douglas \& Wier & 2005 & Differences between US and Chinese managers' incentives to create slack \\
\hline
\end{tabular}


Table 1c. Literature Review Only Articles

\begin{tabular}{lcl}
\hline Author(s) & Year & Theoretical Premise \\
\hline Panel D: Three plus country studies & \\
Svensson et al. & 1994 & Australia, Canada, and Sweden; UA positively associated with rules about dealing with unpredictability \\
Nyaw \& Ng & 1994 & Canada, Japan, Hong Kong and Taiwan \\
Husted & 2002 & Latin American countries \\
Gulbro \& Herbig & 1998 & Mexico, China, France, Japan, and Germany \\
Sims \& Gegez & 2004 & US, Australia, Israel, South Africa, and Turkey, \\
Bernardi \& Guptill & 2008 & US, Canada, Colombia, Ecuador, Hong Kong, and Ireland \\
Freeman \& Hasnaoui & 2011 & US, Canada, France and UK \\
Baker \& Veit & 1998 & US, Canada, Hong Kong, Japan, Singapore, and Thailand \\
Sower et al. & 1998 & US, Canada, and Mexico \\
Ramasamy \& Yeung & 2009 & US, China, France, Germany, and Hong Kong \\
Habisch et al. & 2011 & US, Germany and Italy \\
Shafer et al. & 2007 & US, Hong Kong, Malaysia, and Taiwan \\
Burnaz et al. & 2009 & US, Thailand and Turkey \\
Bernardi et al. & 2009 & Ethical decisions in US, Colombia, Ecuador, and South Africa \\
At-Twaijri & 1996 & Gulf Cooperation Council Countries and finds a recent overall increase in UA due to political \\
Al-Muhaiza & & instability and threats of larger, neighboring countries \\
\hline Italicized data indicate publications in the IJoVBM and TBE. \\
UA - Uncertainty Avoidance
\end{tabular}

The authors of the articles in Table 1 suggest differences other than those discussed by Hofstede. These include: high UA and less whistle-blowing (Zhang et al., 2009; Cohen et al., 1992); being less likely to perceive ethical problems (Cherry, 2006; Cherry et al., 2003); and referring to other professional codes of ethics when forming one's code (Vitell et al, 1993; Thorne \& Saunders, 2002). In Panel A, results indicate that with high levels of uncertainty, people will be less likely to question rules (Rallapalli, 1999; Cohen et al., 1992) and have a greater intolerance of deviation from group norms (Vega, 1997). In Panel C, the following articles associated high UA with increased ethical reasoning (Tsui \& Windsor, 2001), increased cheating (Srnka et al., 2007), increased level of importance of ethical problems (Tavakoli et al., 2003; Sims \& Kennan, 1999), increased amount of employees placing their company's interests above their own interests (Vitell \& Hidalgo, 2006) and increased probability that when faced with an ethical dilemma, one would follow the stated rules instead of making their own decision (Rawwas et al., 2005). Two articles in Panel D indicated that when there is high UA, there is a greater need for written rules (Sower et al., 1998) and concern about following the rules (Bernardi et al., 2009).

There is an overlap that occurs among panels; Panel A and C use UA to suggest differences in breaking company rules (Goodwin \& Goodwin, 1999; Throne \& Saunders, 2002; Cohen et al., 1992; Ge \& Thomas, 2008; Lu et al., 1999). Panels B and C illustrate the potential differences using UA and the severity of perceptions of violations of ethics (Armstrong, 1996; Sims \& Keenan, 1999) and suggest that UA may result in differences in the likelihood of cheating (Salter et al., 2001; Ge \& Thomas, 2008). Panels C and D suggest a tendency towards rules orientation may differ with UA (Sims \& Kennan, 1999; Sower et al., 1998).

\subsection{Using UA to Construct an Alternative Cultural Indices}

Kogut and Singh (1982) developed a calculation that uses Hofstede's cultural dimensions to construct a single score for each country rather than four individual scores (i.e., if one used Hofstede's dimensions directly). To compute their single index (Formula (1)), Kogut and Singh calculate differences in cultures by subtracting each target country's cultural dimensions (Hofstede, 1980) from the same cultural dimension of a control country, which is usually the United States. Once all of the cultural dimensions have been subtracted, the results are totaled for a single score.

$$
\text { Hofstede's Distance }=\left[\sum_{\mathrm{i}=1}^{4}\left\{\left(I_{i i}-I_{i u}\right]^{2}\right\} / V_{i} / 4\right]
$$

Kogut \& Singh, 1988: 422.

Where

$I_{i j}$ : Index for the $i$ th cultural dimension and $j$ th country; 
$V_{i}$ : Variance of the index of the $i$ th cultural dimension;

$u$ : Indicates the United States

Uhlenbruck's (2004) cultural index (Formula (2)) is the same as Kogut and Singh's index; instead of using Hofstede's cultural dimensions, Uhlenbruck used Trompenaar and Hampden-Turner's (1998) dimensions. Uhlenbruck uses the same technique as Kogut and Singh, which results in a single score for each country. Uhlenbruck uses three of Trompenaar and Hampden-Turner's (1998) dimensions: individualism, specificity and attitudes towards organizations. Table 2 contains three articles that use either the Kogut and Singh index or Uhlenbruck index.

$$
\text { Cultural Distance }=\left[\sum_{\mathrm{ieDa}}\left(I_{i a}-I_{i t}\right)^{2} / \mathrm{V}_{\mathrm{i}} /\left|\mathrm{D}_{\mathrm{at}}\right|\right]
$$

Uhlenbruck, 2004: 117.

Where:

$I_{i a}$ : Index for the $i$ th cultural dimension for the $a$ th country;

$I_{i t}$ : Index for the $i$ th cultural dimension for the $t$ th country;

$V_{i}$ : Variance of the index of the $i$ th cultural dimension;

$\left|D_{\text {at }}\right|$ : Number of compared measures.

Two articles use Kogut and Singh's Index to compare it to UA. Li (2008) used Kogut and Singh to explain the likelihood of joint ventures, while Peng and Beamish (2008) related Kogut and Singh to the predictability of general economic data. The third article used Uhlenbruck to explain cultural differences in ethics (Gopalan \& Thomson, 2003). The final article used Kogut and Singh's index as well as Uhlenbruck's. Voyer and Beamish (2004) used both cultural indices to explain differences between Japan and other countries.

Table 2. Articles Employing a Cultural Index

\begin{tabular}{llll}
\hline Author(s) & Year & Sample & Theoretical Premise \\
\hline Gopalan \& Thomson & 2003 & Theoritical & UA and Trompenaar's used to explain cultural differences in ethics. \\
Li & 2008 & 22,156 firms & UA and Kogut and Singh's Index used to explain likelihood of joint ventures. \\
Peng \& Beamish & 2008 & 50 countries & UA and Kogut and Singh's Index used to predict general economic data. \\
Voyer \& Beamish & 2004 & 9,546 investments & Used Hofstede (Trompenaars and Hampden-Turner's) cultural dimensions and \\
& & 9 countries & Kogut and Singh's Index (Uhlenbruck's Index) to explain differences between \\
& & Japan and another country. \\
\hline
\end{tabular}

Note: Italicized data indicate publications in the $I J O V B M$ and $T B E$. UA - Uncertainty Avoidance.

As mentioned briefly in the introduction, it is difficult to speculate on the association between alternative cultural indices, behavioral contrasts and ethics research due to the small number of articles that appear in Table 2. Of these four articles, none report associations between the alternative cultural index and ethics. This is not to say that these associations do not occur; it was just not evident in these four articles. The lack of research using these indices does, however, suggest a significant opportunity for future research. Such research could consider the general use of alternative cultural indices or examine potential associations between alternative cultural indices and ethics.

\subsection{Using UA as an Independent Variable}

Table 3 presents articles that use UA as an independent variable. As seen from this table, these hypotheses propose associations between cultures or behaviors. Similar to the previous tables, Table 3 is broken into three panels depending on article characteristics. Panel A presents the ten articles that used survey data for statistical analysis. Panel B contains six articles that used country data in the analysis. Panel C has six articles that used alternative sources and firm level data. 
Table 3a. Articles Employing Uncertainty Avoidance as a Variable

\begin{tabular}{|c|c|c|c|}
\hline Author(s) & Year & Sample/Countries & Findings Relating to Culture \\
\hline \multicolumn{4}{|c|}{ Panel A: Human-participant studies } \\
\hline Lin \& Ho & 2010 & 466 adults $/ 2$ & UA higher in Taiwan than China \\
\hline Auger et al. & 2007 & 600 adults $/ 6$ & UA positively associated with worker, labor and individual rights \\
\hline Kim \& Kim & 2010 & $\begin{array}{l}125 \text { adults/ } \\
\text { South Korea }\end{array}$ & $\begin{array}{l}\text { UA positively associated with good business, commitment, PR role and total } \\
\text { corporate social responsibility }\end{array}$ \\
\hline Tan \& Chow & 2009 & 58 adults $/ 2$ & $\begin{array}{l}\text { Differences in attitudes found between US Caucasians and Chinese (in either } \\
\text { China or US). }\end{array}$ \\
\hline Peek et al. & 2007 & 78 Students $/ 3$ & $\begin{array}{l}\text { UA associated with attitudes concerning sexual harassment and whistle blowing } \\
\text { among students from Canada, Mexico and US. }\end{array}$ \\
\hline Arnold et al. & 2007 & 294 adults $/ 8$ & UA not associated with measures of sensitivity. \\
\hline Bernardi & 2006 & 1,537 students $/ 12$ & UA positively associated with social desirability response bias. \\
\hline Forsyth et al. & 2008 & 30,230 adults $/ 29$ & UA positively associated with Relativism \\
\hline Christie et al. & 2003 & 345 adults $/ 3$ & UA associated with questionable ethical behavior in US, Korea and India \\
\hline Smith & 2011 & $\begin{array}{l}135 \text { students/ } \\
\text { United States }\end{array}$ & $\begin{array}{l}\text { Used different measures which approximated Hofstede's values and found UA } \\
\text { positively associated with collectivism, long-term orientation, idealism and } \\
\text { transformational leadership }\end{array}$ \\
\hline
\end{tabular}

Table 3b. Articles Employing Uncertainty Avoidance as a Variable

\begin{tabular}{|c|c|c|c|}
\hline Author(s) & Year & Sample/Countries & Findings Relating to Culture \\
\hline \multicolumn{4}{|c|}{ Panel B: Country-based studies } \\
\hline Baughn et al. & 2010 & 125 & UA positively associated with OECD convention ratification \\
\hline Li et al. & 2008 & 133 & UA positively associated with Corruption Perception Index \\
\hline Davis \& Ruhe & 2003 & 42 & $\begin{array}{l}\text { UA positively associated with preference for bureaucratic structures, nationalism, } \\
\text { Corruption Perception Index, and unethical behavior. }\end{array}$ \\
\hline Sanyal & 2005 & 30 & UA positively associated with Corruption Perception Index \\
\hline Peng \& Lin & 2009 & 51 & UA negatively associated with individualism \\
\hline Husted & 2000 & 50 & $\begin{array}{l}\text { No association between UA and other cultural dimensions with software piracy } \\
\text { using World Bank data. }\end{array}$ \\
\hline \multicolumn{4}{|c|}{ Panel C: Other studies } \\
\hline Author(s) & Year & Firms/Countries & Findings Relating to Culture \\
\hline Johan \& Najar & 2010 & 123 & UA positively associated with high efficiency and high performance fees \\
\hline Cummings et al. & 2010 & 528 & $\begin{array}{l}\text { UA positively (negatively) associated with the Masculinity index and Corruption } \\
\text { Perception index (Power Distance index) }\end{array}$ \\
\hline Clements et al. & 2009 & 104 & UA positively (negatively) associated with PDI (IDV) \\
\hline Scholtens \& Dam & 2007 & $2683 / 24$ & UA is positively associated with a firm's ethical policies \\
\hline Alas & 2006 & $\begin{array}{l}\text { Estonian } \\
\text { Organizations }\end{array}$ & UA positively (negatively) associated with values (practices) of ethics \\
\hline Chen et al. & 2008 & $2,018 / 55$ & UA not significant for variables examined \\
\hline
\end{tabular}

Note: Italicized data indicate publications in the IJoVBM and TBE. UA - Uncertainty Avoidance.

Panel A includes articles with data from surveys of either students or adult college graduates in the workforce. Two articles use UA to suggest differences between cultures. Lin \& Ho (2010) contrast the differences in UA between Taiwan and China, and Tan \& Chow (2009) explain cultural differences between American Caucasians and people of Chinese descent who reside in either China or the United States. Five describe potential positive associations between UA and worker, labor and individual rights (Auger et al., 2007); good business, commitment, public relations role and corporate social responsibility (Kim \& Kim, 2010); social desirability response bias (Bernardi, 2006); relativism (Forsyth et al., 2008) and, collectivism, long-term orientation, idealism and transformational leadership (Smith, 2011). In one article, Arnold et al. (2007) discovered a negative association between UA and measures of sensitivity. The last two articles found a relationship between UA and a behavior, but did not state whether this relationship was positive or negative. Peek et al. (2007) associated whistle-blowing and sexual harassment to UA; Christie et al. (2003) associated questionable ethical behavior with UA.

Panel B contains articles that utilize UA as an independent variable and publicly available database information 
from a variety of sources in the analysis. The sample sizes range from 30-to-133 countries. Four articles found positive associations with UA, one found a negative association and one found no association. UA was positively associated with OECD convention ratification (Baugh et al., 2010), corruption perception index (Li et al., 2008; Davis \& Ruhe, 2003; Sanyal, 2005) and preference for bureaucratic structures, nationalism and unethical behavior (Davis \& Ruhe, 2003). UA was negatively associated with individualism (Peng and Li, 2009). Husted (2000) found no association between UA and software piracy.

Panel C has six articles that used firm level alternative sample sources. Johan and Najar (2010) collected a sample from 123 firms which represented 23 countries. This article found that UA is positively associated with high efficiency and high performance fees. The next one included a sample from 528 firms in 20 countries (Cumming et al., 2010). This article found that UA is positively associated with Hofstede's masculinity dimension and the Corruption Perception Index as well as negatively associated with the power distance dimension. Clements et al. (2009) had a sample of 104 accounting firms; this article found that UA is positively associated with power distance and is negatively associated with individualism. Scholtens and Dam (2007) collected data from 2683 firms that came from 24 countries; these authors showed that UA is positively related with a firm's ethical policies. The third article in Panel $\mathrm{C}$ had a sample that utilized information from Estonian organizations (Alas, 2006). While Alas found that UA is positively associated with values of ethics, UA was negatively associated with the practice of ethics. The last article (Chen et al., 2008) had a sample from 2,018 firms representing 55 countries, which found no significant associations between UA and the variables examined.

The articles assigned to Table 3 incorporate an increased level of use of UA in ethics research, especially when creating, testing and discussing variables. These articles use both Hofstede's discussed associations as well as independent associations created by the authors. There are five articles that directly use Hofstede's suggested relationships between UA and ethics. In Panel A, two articles used Hofstede's potential connections (Table 3) between two factors. These articles found that, in high UA societies, only known risks are taken (Kim \& Kim, 2010) and that there is preference for tasks with sure outcomes, no risks and following instructions (Peek et al., 2007). In Panel B, there is one article that uses Hofstede's potential differences. Davis and Ruhe (2003) found that high UA associates with an increased resistance to change. As seen in Panel C, Clements et al. (2000) found that as UA increases resistance to change also increases. Alas (2006) found that high UA societies believe that company rules should not be broken.

There were 15 articles with associations that were not suggested by Hofstede. The Panel A studies indicated that in high UA countries there is a preference for: a structured environment (Auger et al., 2007), more rules and standards (Kim \& Kim, 2010), following rules and procedures (Peek et al., 2007), and leaders who have clear rules, procedures and guidelines (Smith, 2010). High UA countries also display increased: ethical sensitivity towards stakeholders (Kim \& Kim, 2010), focus on legality instead of ethics (Christie et al., 2003), corruption (Arnold et al., 2007; Bernardi, 2006), social desirability response bias (Bernardi, 2006), and a lower tendency to whistle-blow (Peek et al., 2007). Panel A has more associations between UA and ethics than the other two panels of Table 3. In Panel B, there were three articles that included other potential differences. When UA is high: corruption is higher ( $\mathrm{Li}$ et al., 2008); preference for structured order is higher (Davis \& Ruhe, 2003); and, a decreased likelihood of recognizing ethical issues in the absence of formal rules (Husted, 2000).

The associations between high UA and high corruption can be found in Panels A and B (Bernardi, 2006; Li et al., 2008; Davis \& Ruhe, 2003). Associations between high UA and more resistance to change are found in Panels B and C (Davis \& Ruhe, 2003; Clements et al., 2009). The associations shown in this table between UA and ethics play a greater role in these articles than those in other tables because these variables were used directly rather than solely as support material.

\section{Discussion and Conclusions}

The data indicate that $66.2 \%$ of the articles used uncertainty avoidance strictly in the literature review to construct hypotheses, $5.2 \%$ to construct alternative cultural indices and $28.6 \%$ as an independent variable. However, an important difference between the data in this research and in Rapp et al. (2011) is that, while Rapp et al. found that 100 of the $118(84.7 \%)$ articles they identified were in the three categories we examined, only 77 of the $161(47.8 \%)$ articles we identified were in these three categories. Consequently, while the percentage comparison between studies may appear to be similar, the article counts represented are dramatically different.

In this research, only four of the 77 articles (5.2\%) used Hofstede's cultural constructs in the computation of cultural distance indices; this compares to 29 of the 100 articles (29.0\%) that Rapp et al. (2011) reported which used this methodology. This difference suggests that the use of Kogut and Singh's (1988) and Uhlenbruck's 
(2004) indices has not been adopted by ethics scholars, which presents an avenue for future research. The remaining 22 articles $(28.6 \%)$ were the only ones that used UA as an independent or control variable compared to the $30.0 \%$ that Rapp et al. found. The relative absence of the use of Kogut and Singh's and Uhlenbruck's indices (5.2\% versus $29.0 \%$ ) between ethics research and research published in the Journal of International Business Studies is striking. Taken together, the current research and Rapp et al. (2011) provide a useful indicator for future research areas in ethics research. There are ample opportunities for comparing samples from various countries using either Kogut and Sing's and Uhlenbruck's indices or UA as an independent variable (i.e., Bernardi, 2006) that could provide insights to differences in international behavior and/or perceptions.

Table 4. Associations between Hofstede's Uncertainty Avoidance and Ethics Research

\begin{tabular}{|c|c|}
\hline Low Uncertainty Avoidance & High Uncertainty Avoidance \\
\hline If necessary, employees may break rules. & Company rules should not be broken. \\
\hline Goodwin \& Goodwin (1999) - 1A & Thorne \& Saunders (2002) - 1A \\
\hline \multirow[t]{3}{*}{ Cohen et al. (1992) - 1A } & Ge \& Thomas (2008) - 1C \\
\hline & Lu et al. (1999) - 1C \\
\hline & Alas $(2006)-3 C$ \\
\hline Less resistance to changes. & More resistance to changes. \\
\hline \multirow[t]{2}{*}{ Davis \& Ruhe (2003) - 3B } & Vega (1997) - 1A \\
\hline & Clements et al. (2009) - 3C \\
\hline Willingness to take unknown risks. & Only known risks are taken. \\
\hline Swaidan et al. (2006) - 1B & $\operatorname{Kim} \& \operatorname{Kim}(2010)-3 A$ \\
\hline \multirow[t]{2}{*}{ Hope for success. } & Fear of failure. \\
\hline & Armstrong (1996) - 1B \\
\hline \multirow[t]{2}{*}{$\begin{array}{l}\text { Preference for tasks with uncertain outcomes, calculated } \\
\text { risks, and requiring problem solving. }\end{array}$} & $\begin{array}{l}\text { Preference for tasks with sure outcomes, no risks, and } \\
\text { following instructions. }\end{array}$ \\
\hline & Peek et al. (2007) - 3A \\
\hline $\begin{array}{l}\text { Laypersons in key positions; high ratio of nurses to } \\
\text { doctors. }\end{array}$ & $\begin{array}{l}\text { Experts in key positions; low ratio of nurses to doctors. } \\
\text { At-Twaijri \& Al-Muhaiza (1996) - 1D }\end{array}$ \\
\hline In wealthy countries, less corruption. & In wealthy countries, more corruption. \\
\hline Volkema \& Fleury (2002) - 1A & \\
\hline
\end{tabular}

Table 4 summarizes associations related to Hofstede's UA index. Panel A illustrates seven of Hofstede's stated associations between UA and ethics. These include both low and high UA. The articles with findings related to low UA stated that, if necessary, employees may break rules (Goodwin \& Goodwin, 1999; Cohen et al., 1992), there is less resistance to changes (Davis \& Ruhe, 2003), willingness to take unknown risks (Swaidan et al., 2006) and there is less corruption in wealthy countries (Volkema \& Fleury, 2002). The articles that had findings associated with high UA stated that company rules should not be broken (Thorne \& Saunders, 2002; Ge \& Thomas, 2008; Lu et al., 1999; Alas, 2006), there is more resistance to changes (Vega, 2007; Clements et al., 2009), only known risks are taken (Kim \& Kim, 2010), there is fear of failure (Armstrong, 1996), preference is for tasks with certainty in outcomes, no risks and following instructions (Peek et al., 2007) and when experts are in key positions (At-Twaijri \& Al-Muhaiza, 1996).

A limitation of our research is that it considered only articles in three ethics journals: the JoBE, the IJoVBM and $T B E$; of these journals, the last two have not been published since 2003. This limitation also provides the opportunity for future research which could examine the use of Hofstede's UA construct in other fields and topical areas to determine whether the results of this research are supported.

\section{References}

Alas, R. (2006). Ethics in countries with different cultural dimensions. Journal of Business Ethics, 69(3), 237-247. http://dx.doi.org/10.1007/s10551-006-9088-3

Armstrong, R. W. (1996). The relationship between culture and perception of ethical problems in international Marketing. Journal of Business Ethics, 15(11), 1199-1208. http://dx.doi.org/10.1007/BF00412818

Arnold, D. F., Bernardi, R. A., Neidermeyer, P. E., \& Schmee, J. (2007). The Effect of Country and Culture on Perceptions of Appropriate Ethical Actions Prescribed by Codes of Conduct: A Western European Perspective among Accountants. Journal of Business Ethics, 70(4), 327-340. http://dx.doi.org/10.1007/s10551-006-9113-6

At-Twaijri, M. I., \& Al-Muhaiza, I. A. (1996). Hofstede's Cultural Dimensions in the GCC Countries: An 
Empirical Investigation. International Journal of Value-Based Management, 9(2), 121-131. http://dx.doi.org/10.1007/BF00440149

Auger, P., Devinney, T. M., \& Louviere, J. J. (2007). Using Best-Worst Scaling Methodology to Investigate Consumer Ethical Beliefs Across Countries. Journal of Business Ethics, 70(3), 299-326. http://dx.doi.org/10.1007/s10551-006-9112-7

Baker, H. K., \& Veit, E. T. (1998). A Comparison of Ethics of Investment Professionals: North America versus Pacific Rim Nations. Journal of Business Ethics, 17(8), 917-937. http://dx.doi.org/10.1023/A:1005708319253

Baughn, C., Bodie, N. L., Buchanan, M. A., \& Bixby, M. B. (2010). Bribery in International Business Transactions. Journal of Business Ethics, 92(1), 15-32. http://dx.doi.org/10.1007/s10551-009-0136-7

Beekun, R. I., Hamdy, R., Westerman, J. W., \& Hassab Elnaby, H. R. (2008). An Exploration of Ethical Decision-making Processes in the United States and Egypt. Journal of Business Ethics, 82(3), 587-605. http://dx.doi.org/10.1007/s10551-007-9578-y

Beekun, R. I., Stedham, Y., \& Yamamura, J. H. (2003). Business Ethics in Brazil and the U.S. A Comparative Investigation. Journal of Business Ethics, 42(3), 267-279. http://dx.doi.org/10.1023/A:1022200702149

Bernardi, R. A. (2006). Associations between Hofstede's Cultural Constructs and Social Desirability Response Bias. Journal of Business Ethics, 65(1), 46-56. http://dx.doi.org/10.1007/s10551-005-5353-0

Bernardi, R. A., \& Guptill, S. (2008). Social Desirability Response Bias, Gender, and Factors Influencing Organizational Commitment: An International Study. Journal of Business Ethics, 81(4), 797-809. http://dx.doi.org/10.1007/s10551-007-9548-4

Bernardi, R. A., Witek, M. B., \& Melton, M. R. (2009). A Four-Country Study of the Associations between Bribery and Unethical Actions. Journal of Business Ethics, 84(3), 389-403. http://dx.doi.org/10.1007/s10551-008-9715-2

Burnaz, S., Atakan, M. G. S., Topcu, Y. I., \& Singhapakdi, A. (2009). An Exploratory Cross-Cultural Analysis of Marketing Ethics: The Case of Turkish, Thai, and American Businesspeople. Journal of Business Ethics, 90(3), 371-382. http://dx.doi.org/10.1007/s10551-010-0422-4

Caldwell, C., \& Clapham, S. E. (2003). Organizational Trustworthiness: An International Perspective. Journal of Business Ethics, 47(4), 349-364. http://dx.doi.org/10.1023/A:1027370104302

Chen, Y., Yaar, M., \& Rejesus, R. M. (2008). Factors Influencing the Incidence of Bribery Payouts by Firms: A Cross-Country Analysis. Journal of Business Ethics, 77(2), 231-244. http://dx.doi.org/10.1007/s10551-006-9346-4

Cherry, J., Lee, M., \& Chien, C. S. (2003). A Cross-Cultural Application of a Theoretical Model of Business Ethics: Bridging the Gap between Theory and Data. Journal of Business Ethics, 44(4), 359-376. http://dx.doi.org/10.1023/A:1023615520293

Christie, P. M. J., Kwon, I. G., Stoeberl, P. A., \& Baumhart, R. (2003). A Cross-Cultural Comparison of Ethical Attitudes of Business Managers: India Korea and the United States. Journal of Business Ethics, 46(3), 263-287. http://dx.doi.org/10.1023/A:1025501426590

Clements, C. E., Neill, J. D., \& Stovall, O. S. (2009). The Impact of Cultural Differences on the Convergence of International Accounting Codes of Ethics. Journal of Business Ethics, 90(3), 383-391. http://dx.doi.org/10.1007/s10551-010-0417-1

Cohen, J. R., Pant, L.W., \& Sharp, D. J. (1992). Cultural and Socioeconomic Constraints on International Codes of Ethics: Lessons from Accounting. Journal of Business Ethics, 11(9), 687-700. http://dx.doi.org/10.1007/BF01686349

Cummings, D., Fleming, G., Johan, S., \& Takeuchi, M. (2010). Legal protection, corruption and private equity returns in Asia. Journal of Business Ethics, 95(2), 173-193. http://dx.doi.org/10.1007/s10551-011-0853-6

Daspro, E. (2009). An Analysis of U.S. Multinationals' Recruitment Practices in Mexico. Journal of Business Ethics, 87(1), 221-232. http://dx.doi.org/10.1007/s10551-008-9805-1

Davis, J., \& Ruhe, J. A. (2003). Perceptions of Country Corruption: Antecedents and Outcomes. Journal of Business Ethics, 43(4), 277-288. http://dx.doi.org/10.1023/A:1023038901080

De Bock, T., \& Van Kenhove, P. (2010). Consumer Ethics: The Role of Self-Regulatory Focus. Journal of Business Ethics, 97(2), 241-255. http://dx.doi.org/10.1007/s10551-010-0507-0

Douglas, P. C., \& Wier, B. (2005). Cultural and Ethical Effects in Budgeting Systems: A Comparison of U.S. and Chinese Managers. Journal of Business Ethics, 60(2), 159-174. http://dx.doi.org/10.1007/s10551-004-6711-z

Fadil, P. A. (1997). The Influence of Cultural Adaptation on Hispanic-Americans and Japanese-Americans. $\begin{array}{llll}\text { International Journal of } & \text { Value-Based }\end{array}$ 
http://dx.doi.org/10.1023/A:1007709019989

Forsyth, D. R., O'Boyle, E. H., \& McDaniel, M. A. (2008). East Meets West: A Meta-Analytic Investigation of Cultural Variations in Idealism and Relativism. Journal of Business Ethics, 83(4), 813-833. http://dx.doi.org/10.1007/s10551-008-9667-6

Freeman, I., \& Hasnaoui, A. (2011). The Meaning of Corporate Social Responsibility: The Vision of Four Nations. Journal of Business Ethics, 100(3), 419-443. http://dx.doi.org/10.1007/s10551-010-0688-6

Ge, L., \& Thomas, S. (2008). A Cross-Cultural Comparison of the Deliberative Reasoning of Canadian and Chinese Accounting Students. Journal of Business Ethics, 82(1), 189-211. http://dx.doi.org/10.1007/s10551-007-9571-5

Goel, S., Bell, G. G., \& Pierce, J. L. (2005). The Perils of Pollyanna: Development of the Over-Trust Construct. Journal of Business Ethics, 58(1), 203-218. http://dx.doi.org/10.1007/s10551-005-1415-6

Goodwin, J., \& Goodwin, D. (1999). Ethical Judgment across Cultures: A Comparison between Business Students from Malaysia and New Zealand. Journal of Business Ethics, 18(3), 267-281. http://dx.doi.org/10.1023/A:1005785020162

Gopalan, S., \& Thomson, N. (2003). National Cultures, Information Search Behaviors and the Attribution Process of Cross-National Managers: A Conceptual Framework. Teaching Business Ethics, 7(3), 313-328. http://dx.doi.org/10.1023/A:1025029421972

Gulbro, R. D., \& Herbig, P. (1998). Cultural Differences in International Negotiating. International Journal of Value-Based Management, 11(3), 265-273. http://dx.doi.org/10.1023/A:1007759418798

Habisch, A., Patelli, L., Pedrini, M., \& Schwartz, C. (2011). Different Talks with Different Folks: A Comparative Survey of Stakeholder Dialog in Germany, Italy, and the U.S. Journal of Business Ethics, 100(3), 381-404. http://dx.doi.org/10.1007/s10551-010-0686-8

Hoffman, J. J. (1998). Evaluating International Ethical Climate: A Goal Programming Model. Journal of Business Ethics, 17(16), 1861-1869. http://dx.doi.org/10.1023/A:1005820410387

Hofstede, G. (1980). Culture's Consequences: Comparing Values, Behaviors, Institutions, and Organizations across Countries. Beverly Hills, CA: Sage Publications.

Hofstede, G. (1991). Organizations and cultures: Software of the mind. New York: McGraw-Hill.

Husted, B. (2000). The Impact of National Culture on Software Piracy. Journal of Business Ethics, 26(3), 197-211. http://dx.doi.org/10.1023/A:1006250203828

Husted, B. (2002). Culture and International Anti-Corruption Agreements in Latin America. Journal of Business Ethics, 37(4), 413-422. http://dx.doi.org/10.1023/A:1015248921716

Johan, S. A., \& Najar, D. (2010). The role of corruption, culture, and law in investment fund manager fees. Journal of Business Ethics, 95(2), 147-172. http://dx.doi.org/10.1007/s10551-011-0852-7

Kim, G. S., Lee, G. Y., \& Park, K. (2010). A Cross-National Investigation on How Ethical Consumers Build Loyalty toward Fair Trade Brands. Journal of Business Ethics, 96(4) 589-611. http://dx.doi.org/10.1007/s10551-010-0486-1

Kim, Y., \& Kim, S. Y. (2010). The Influence of Cultural Values on Perceptions of Corporate Social Responsibility: Application of Hofstede's Dimensions to Korean Public Relations Practitioners. Journal of Business Ethics, 91(4), 485-500. http://dx.doi.org/10.1007/s10551-009-0095-z

Kogut, B., \& Singh, H. (1988). The Effect of National Culture on the Choice of Entry Mode. Journal of International Business Studies, 19(3), 411-432. http://dx.doi.org/10.1057/palgrave.jibs.8490394

Li, J., Moy, J., Lam, K., \& Chu, W. L. (2008). Institutional Pillars and Corruption at the Societal Level. Journal of Business Ethics, 83(2), 327-229. http://dx.doi.org/10.1007/s10551-007-9622-y

Li, N. (2008). Religion, Opportunism, and International Market Entry via Non-Equity Alliance or Joint Ventures. Journal of Business Ethics, 80(4), 771-789. http://dx.doi.org/10.1007/s10551-007-9468-3

Lin, C. L., \& Yeh, J. T. (2009). Comparing Society's Awareness of Women: Media-Portrayed Idealized Images and Physical attractiveness. Journal of Business Ethics, 90(1), 61-79. http://dx.doi.org/10.1007/s10551-009-0026-z

Lin, L. H., \& Ho, Y. L. (2010). Guanxi and OCB: The Chinese Cases. Journal of Business Ethics, 96(2), 285-298. http://dx.doi.org/10.1007/s10551-010-0465-6

Lu, L. C., Rose, G. M., \& Blodgett, J. G. (1999). The Effects of Cultural Dimensions on Ethical Decision Making in Marketing: An Exploratory Study. Journal of Business Ethics, 18(1), 91-105. http://dx.doi.org/10.1023/A:1006038012256

Nyaw, M., \& Ng, I. (1994). A Comparative Analysis of Ethical Beliefs: A Four Country Study. Journal of Business Ethics, 13(7), 543-555. http://dx.doi.org/10.1007/BF00881299

Oumlil, A. B., \& Balloun, J. L. (2009). Ethical Decision-Making Differences between American and Moroccan 
Managers. Journal of Business Ethics, 84(4), 457-478. http://dx.doi.org/10.1007/s10551-008-9719-y

Parnell, J. A., \& Kedia, B. L. (1996). The Impact of National Culture on Negotiating Behaviors Across Borders. International Journal of Value-Based Management, 9(1), 45-61. http://dx.doi.org/10.1007/BF00420507

Peek, L., Roxas, M., Peek, G., Robinchaud, Y., Covarrubias Salazar, B. E., \& Barragan Codina, J. N. (2007). NAFTA Students' Whistle-Blowing Perceptions: A Case of Sexual Harassment. Journal of Business Ethics, 74(3), 219-231. http://dx.doi.org/10.1007/s10551-006-9231-1

Peng, G. Z., \& Beamish, P. W. (2008). The Effect of National Corporate Responsibility Environment on Japanese Foreign Direct Investment. Journal of Business Ethics, 80(4), 677-695. http://dx.doi.org/10.1007/s10551-007-9462-9

Peng, Y. S., \& Lin, S. S. (2009). National Culture, Economic Development, Population Growth and Environmental Performance: The Mediating Role of Education. Journal of Business Ethics, 90(2), 203-219. http://dx.doi.org/10.1007/s10551-009-0036-x

Rallapalli, K. C. (1999). A Paradigm for Development and Promulgation of Global Code of Marketing Ethics. Journal of Business Ethics, 18(1), 125-137. http://dx.doi.org/10.1023/A:1006076530003

Ramasamy, B., \& Yeung, M. (2009). Chinese Consumers' Perception of Corporate Social Responsibility (CSR). Journal of Business Ethics, 88(1), 119-132. http://dx.doi.org/10.1007/s10551-008-9825-x

Rapp, J. K., Bernardi, R. A., \& Bosco, S. M. (2011). Examining the Use of Hofstede's Uncertainty Avoidance Construct in International Research: A 25-Year Review. International Business Research, 4(1), 3-15.

Rawwas, M. Y., Swaidan, A. Z., \& Oyman, M. (2005). Consumer Ethics: A Cross-Cultural Study of the Ethical Beliefs of Turkish and American Consumers. Journal of Business Ethics, 57(2), 183-195. http://dx.doi.org/10.1007/s10551-004-5092-7

Robertson, C. J., Crittenden, W. F., Brady, M. K., \& Hoffman, J. J. (2002). Situational Ethics across Boarders: A $\begin{array}{lllll}\text { Multicultural Examination. Journal of Business Ethics, 38(4), 327-338. } & \text {. }\end{array}$ http://dx.doi.org/10.1023/A:1016067231599

Salter, S. B., Guffey, D. M., \& McMillan, J. J. (2001). Truth, Consequences and Culture: A Comparative Examination of Cheating and Attitude about Cheating among U.S. and U.K. Students. Journal of Business Ethics, 31(1), 37-50. http://dx.doi.org/10.1023/A:1010785106667

Sanyal, R. (2005). Determinants of Bribery in International Business: The Cultural and Economic Factors. Journal of Business Ethics, 59(1), 139-145. http://dx.doi.org/10.1007/s10551-005-3406-z

Scholtens, B., \& Dam, L. (2007). Cultural Values and International Differences in Business Ethics. Journal of Business Ethics, 75(3), 273-284. http://dx.doi.org/10.1007/s10551-006-9252-9

Shafer, W. E., Fukukawa, K., \& Lee, G. M. (2007). Values and the Perceived Importance of Ethics and Social Responsibility: The U.S. versus China. Journal of Business Ethics, 70(3), 265-284. http://dx.doi.org/10.1007/s10551-006-9110-9

Sims, R. L., \& Gegez, A. E. (2004). Attitudes towards Business Ethics: A Five Nation Comparative Study. Journal of Business Ethics, 50(3), 253-265. http://dx.doi.org/10.1023/B:BUSI.0000024708.07201.2d

Sims, R. L., \& Keenan, J. P. (1999). A Cross-Cultural Comparison of Managers' Whistleblowing Tendencies. International Journal of Value-Based Management, 12(2), 137-151. http://dx.doi.org/10.1023/A:1007711220997

Smith, B. (2011). Who Shall Lead Us? How Cultural Values and Ethical Ideologies Guide Young Marketers' Evaluations of the Transformational Manager-Leader. Journal of Business Ethics, 100(4), 633-645. http://dx.doi.org/10.1007/s10551-010-0701-0

Sower, V. E., Abshire, R. D., \& Shankman, N. A. (1998). A Cross-Cultural Study of the Ethical Orientations of Senior-Level Business Students. Teaching Business Ethics, 1(4), 379-397 http://dx.doi.org/10.1023/A:1009702012515

Srnka, K. J., Gegez, A. E., \& Arzova, S. B. (2007). Why Is It (Un-)ethical? Comparing Potential European Partners: A Western Christian and An Eastern Islamic Country - On Arguments Used in Explaining Ethical Judgments. Journal of Business Ethics, 74(2), 101-118. http://dx.doi.org/10.1007/s10551-006-9223-1

Svensson, G., Wood, G., Singh, J., Carasco, E., \& Callaghan, M. (2009). Ethical Structures and Processes of Corporations Operating in Australia, Canada, and Sweden: A Longitudinal and Cross-Cultural Study. Journal of Business Ethics, 86(4), 485-506. http://dx.doi.org/10.1007/s10551-008-9860-7

Swaidan, Z., Vitell, S. J., Rose, G. M., \& Gilbert, F. W. (2006). Consumer Ethics: The Role of Acculturation in U.S. Immigrant Populations. Journal of Business Ethics, 64(1), 1-16. http://dx.doi.org/10.1007/s10551-005-4663-6

Tan, J., \& Chow, I. H. (2009). Isolating Cultural and National Influence on Value and Ethics: A Test of

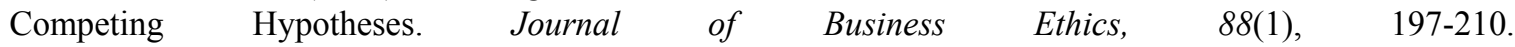


http://dx.doi.org/10.1007/s10551-008-9822-0

Tavakoli, A. A., Keenan, J. P., \& Cranjak-Karanovic, B. (2003). Culture and Whistle-Blowing: An Empirical Study of Croatian and United States Managers Utilizing Hofstede's Cultural Dimensions. Journal of Business Ethics, 43(1), 49-64. http://dx.doi.org/10.1023/A:1022959131133

Thorne, L., \& Saunders, S. B. (2002). The Socio-Cultural Embeddedness of Individuals' Ethical Reasoning in Organizations (Cross-cultural Ethics). Journal of Business Ethics, 35(1), 1-14. http://dx.doi.org/10.1023/A:1012679026061

Transparency International. (2010). Corruption Perceptions Index, accessed on Sept. 18, 2011. www.transparency. org/policy_research/surveys_indices/cpi/2010.

Trompenaars, F., \& Hampden-Turner, C. (1998). Riding The Waves of Culture: Understanding Diversity in Global Business. New York: McGraw Hill.

Tsui, J., \& Windsor, C. (2001). Some Cross-Cultural Evidence on Ethical Reasoning. Journal of Business Ethics, 31(2), 143-150. http://dx.doi.org/10.1023/A:1010727320265

Uhlenbruck, K. (2004). Developing Acquired Foreign Subsidiaries: The Experience of MNES in Transition Economies. Journal of International Business Studies, 35(2), 109-123. http://dx.doi.org/10.1057/palgrave.jibs. 8400070

Van Es, R., \& Pels, T. (2010). The Political Dimension: Added Value for Cross-Cultural Analysis. Nozawa and Smits, Two CEOs and Their Public Statements. Journal of Business Ethics, 91(3), 319-327. http://dx.doi.org/10.1007/s10551-009-0085-1

Vega, G. (1997). Caveat Emptor: Ethical Chauvinism in the Global Economy. Journal of Business Ethics, 16(12), 1353-1362. http://dx.doi.org/10.1023/A:1005714604678

Vitell, S. J., \& Hidalgo, E. R. (2006). The Impact of Corporate Ethical Values and Enforcement of Ethical Codes on the Perceived Importance of Ethics in Business: A Comparison of U.S. and Spanish Managers. Journal of Business Ethics, 64(1), 31-43. http://dx.doi.org/10.1007/s10551-005-4664-5

Volkema, R. J., \& Fleury, M. T. L. (2002). Alternative Negotiating Conditions and the Choice of Negotiation Tactics: A Cross-cultural Comparison. Journal of Business Ethics, 36(4), 381-398. http://dx.doi.org/10.1023/A:1014496017565

Voyer, P. A., \& Beamish, P. W. (2004). The Effect of Corruption on Japanese Foreign Direct Investment. Journal of Business Ethics, 50(3), 211-224. http://dx.doi.org/10.1023/B:BUSI.0000024737.57926.bf

Weaver, G. R. (2001). Ethics Programs in Global Businesses: Culture's Role in Managing Ethics. Journal of Business Ethics, 30(1), 3-15. http://dx.doi.org/10.1023/A:1006475223493

Woodbine, G. F. (2004). Moral Choice and the Declining Influence of Traditional Value Orientations within the Financial Sector of a Rapidly Developing Region of the People's Republic of China. Journal of Business Ethics, 55(1), 43-60. http://dx.doi.org/10.1007/s10551-004-5592-5

Yang, D., Sonmez, M., Bosworth, D., \& Fryxell, G. (2009). Global Software Piracy: Searching for Further Explacountries. Journal of Business Ethics, 87(2), 269-283. http://dx.doi.org/10.1007/s10551-008-9884-z

Zhang, J., Chiu, R., \& Wei, L. (2009). Decision-Making Process of Internal Whistle-Blowing Behavior in China: Empirical Evidence and Implication. Journal of Business Ethics, 88(1), 25-41. http://dx.doi.org/10.1007/s10551-008-9831-z 